\title{
Travails of Out-of-Field Teachers: A Qualitative Inquiry
}

\author{
Elven R. Bugwak (iD) \\ Instructor 1, Davao Oriental State College of Science and Technology, Davao Oriental, Philippines \\ $\triangle$ Corresponding Author: Elven R. Bugwak, E-mail: ebugwak@gmail.com
}

ARTICLE INFORMATION

Received: December 17, 2020

Accepted: February 07, 2021

Volume: 3

Issue: 2

DOI: $10.32996 /$ jweep.2021.3.2.4

\section{KEYWORDS}

Education; out-of-field teaching; tertiary/college teachers; thematic analysis; qualitative-

phenomenological method; Davao

Oriental, Philippines.

\section{ABSTRACT}

This study aimed to describe and understand the lived experiences of Out-of-Field teachers as they teach subjects outside their field of expertise. This qualitative study employed a phenomenological method where ten (10) General Education Tertiary teachers from Davao Oriental, Philippines, were taken as participants. The participants are teaching General Education subjects outside their field of expertise. Data were gathered through in-depth interviews and focus group discussions. It is found out in this study that teachers who are not experts in the subjects they are teaching experienced difficulties and challenges. As to the teachers' experiences with Out-ofField teaching, five (5) major themes emerged: challenging, difficulty in adjusting to the academic content of the subject, difficulty in addressing students' queries, difficulty in establishing authority, and difficulty in employing appropriate teaching approaches. Along these problems are the ways of coping despite their occurrence, such as careful planning of the subject content, employment of varied teaching approaches and strategies, engaging with professional development, peer mentoring, and evaluation/monitoring of learners' development. Moreover, the following are the suggestions of the participants to Out-of-Field teachers: continuing professional development, consultation to experts, hiring of qualified teachers, and assigning of relevant subjects to teachers. Furthermore, it is suggested that future researchers may also conduct a study about the underlying causes of Out-of-Field teaching and what could be the possible solutions to this problem.

\section{Introduction}

Education is essential in our life because it gives us the chance to improve our living ways. To achieve this, we need someone to assist us; our teachers. It is the teacher's prime duty to transfer knowledge and ignite people to learn more from experience. Teaching is exceptionally laborious. It is a many-sided task, and it is said to be the noblest of all professions because it lays the foundation of any discipline dreamt by many. Thus, their efforts are much sought to embark quality education that students deserve. Besides teachers' actions, their educational background is also a necessary component for effective teaching. It is argued that a teacher is expected to show expertise in the subject areas he/she is teaching. However, this is not what is happening (Cinkir \& Kurum, 2015).

In Australia, they have identified many teachers teaching subjects they are not qualified to teach, according to the latest Australia Council for Educational Research. At the lower secondary level, the situation for Mathematics is dire. However, without exact and comparable data figures quoted by the Office of the Chief Scientist, it is revealed that 40 percent of year seven (7) to ten (10) students were taught by an out-of-field Mathematics teacher (Hobbs, 2015).

Furthermore, institutions have tried to address the need to hire skilled and experienced practitioners. Still, if the teachers are qualified, they may be as limited, or even more, so than with faculty who have more teaching experience. Whether teachers have more years serving the academia, the real challenge is developing subject-specific experts into excellent teachers (Henard and Roseveare, 2012).

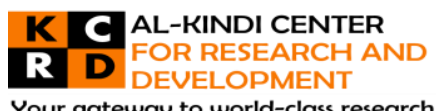

Your gateway to world-class research

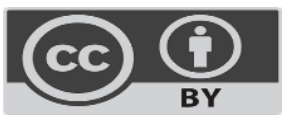

Published by Al-Kindi Center for Research and Development. Copyright (c) the author(s). This open access article is distributed under a Creative Commons Attribution (CC-BY) 4.0 license 
Each one of the Filipino believes that educational attainment is vital to one's life. It is proven that even poor parents make way to send their children to school. However, according to the Organization for Economic Co-operation and Development (OECD) in PISA 2018, Among 79 countries, the Philippines ranked lowest in reading comprehension and second-lowest among the same countries in Science and Mathematics. Thus, despite everyone's effort to pursue education, the DepEd emphasized that the problem that dramatically affects their quest for quality education is mainly attributed to the few numbers of teacher-education graduates who are specialists or prominent in such subject. Hence, it is found out that teachers' performance on knowledge assessments is poor (Demombynes, 2018).

Moreover, Aristotle stressed that understanding rested on one's ability to transfer knowledge to teaching. Demanding teachers to be subject specialists is very great across the primary curriculum which does not restrict them to understand how pupils learn in different subjects and what pupils need to know (House, 2009). However, from understandings are experts of what they teach, they will deliver the lesson well. Further, it is argued that teachers' subject matter knowledge influences their teaching practice and classroom culture (Supovitz \& Turner, 2000).

Furthermore, according to the Australian Council for Education Research in 2015, many teachers still teach outside their field. While there are little researches about the phenomenon internationally, there is still a dearth of studies conducted about it in a local setting (Bayani \& Guhao, Jr., 2017). Thus, Bayani and Guhao, Jr. (2017) emphasized that the phenomenon is present in all schools. However, few studies are conducted to explore and understand this phenomenon across the country, especially at the tertiary level. Salleh (2013) emphasized that teacher training and preparation are necessary for keeping the quality of teaching and learning in school.

Consequently, most of the teachers at the scope of the study are Out-of-Field teachers. These teachers asserted that they encounter countless problems. These have never been adequately addressed; this served as the foremost reason for the researcher to explore and understand Out-of-Field Teachers' travails.

Hence, this phenomenological study aimed to explore and understand the lived experiences and struggles of Out-of-Field teachers. Furthermore, the researcher used in-depth interviews and focus group discussions in gathering the data. However, this study's results can never be used for complete generalization, but these can be used for further investigation of the phenomenon being studied.

\section{Literature Review}

\subsection{Difference between Out-of-Field and In-Field Teaching}

Ingersoll $(1998 ; 2000 ; 2001 ; 2011)$ stressed that Out-of-Field teaching is not widely understood in education. Hence, in his article on the problem of Out-of-Field teaching, he argued that people don't know how complicated and vital teaching is. Out-of-Field teaching was used by many to refer to those teachers assigned to teach subjects in which they are not specialized (Ingersoll \& Collins, 2018). Furthermore, in the study conducted by Mohd. Salleh and Darmawan (2013) discussed the causes of Out-of-Field teaching and the difference between Out-of-Field and In-Field Teaching. He cited that this phenomenon happens because of the wrong assignment of teachers into the subjects they teach.

Moreover, he emphasized that among the root causes why teachers are assigned to teach non-specialized subjects are; disagreement between teachers' qualification requirement and their assignment, the demands of the teacher union, and the shortages of teachers in a particular field. On the other hand, he discussed the meaning of in-field History teaching, which means a phenomenon where teachers who hold a tertiary major in History Education teach the subject. The aim of this study titled "An Investigation into the Differences between Out-of-Field and In-Field History Teachers' Influence on Students' Learning Experiences in Malaysian Secondary Schools" was to investigate if there were differences in Out-of-Field and in-field teachers in terms of their practice, students' perception on teaching and learning History. The study utilized a quantitative design. Data collection was done through two sets of questionnaires. Research participants were drawn from 18 of the 94 secondary schools in Kuala Lumpur, Malaysia, where 52 History teachers and 1653 students participated. The study concluded that there is no significant difference between in-field and out-of-field teachers in terms of teaching approaches. However, it was found out that there are variables which revealed a substantial difference between In-Field and Out-of-Field teaching such as characteristic of experience, the dimensions of the climate and personalization of education. However, in this study, it is still not determined how out-of-field teachers teach the subjects outside their expertise. Thus, it is also not included in this study whether there is a difference in learning that students get from an In-Field teacher and Out-of-Field teacher. Hence, the study recommended that the Malaysian Government should take steps to address the issue. 


\subsection{Conceptualising Out-of-Field Teaching Practices}

A study conducted by du Plessis (2015) titled "Effective Education: Conceptualising the Meaning of Out-of-Field Teaching Practices for Teachers, Teacher Quality and School Leaders" was completed and is grounded in conceptualizing the meaning of Out-of-Field teaching practices, teacher quality, and school leaders. Thus, the latter concepts have gained international attention. The study utilized in-depth exploration of the implications of Out-of-Field teaching for teacher quality. It unveiled complex teaching and learning environments. Thus, it is discussed in this study that the Out-of-Field phenomenon defines teachers teaching outside their field of training or education. The perspectives of educational directors, principals, teachers, and parents across two countries suggest that out-of-field teaching practices are significant to content knowledge, pedagogical knowledge, and pedagogical content knowledge. The study utilized qualitative investigation. The data of this study were collected through interviews, observations, and document analyses regarding the relations among real-life experiences, out-of-field teaching practices, and teachers' perceived quality. The study outcomes exemplify leadership perceptions, understandings and decisions, school improvement policies, and support programs about out-of field situations in schools. And the study ends with recommendations for education policies and further research on teacher quality linked to the out-of-field phenomenon.

In the study conducted by Weldon (2016), he reported secondary school teachers teaching subjects outside their comfort zone. It presented new data on the extent of out-of-field teaching. He defined out-of-field teaching as a secondary teacher who has not studied at a university for more than one year. They were not able to acquire knowledge about teaching methodology. About 26 percent of teachers at years seven (7) to ten (10) teach a subject in which they have not specialized as part of their teaching load. He added that there are more out-of-field teachers teaching than those who are experienced. He presented that 37 percent of year seven (7) to ten (10) teachers with one-to-two years of experience teaching a subject out-of-field compared to 25 percent of teachers teaching with more than five years of experience. An Out-of-Field teacher teaches about 16 percent of class groups in years seven (7) to ten (10) across Australia. In remote locations, about 26 percent compared to 14 percent are being taught by an Out-of-Field Teacher in metropolitan areas.

On the other hand, in places with low socioeconomic status, 9 percent of class groups in schools are taught by Out-of-Field teachers compared to 13 percent in high socioeconomic status locations. With these numbers, Australia is interested in addressing this issue. The teachers' skillful selection of learning activities, methods, instruction, and assessment strategies depend on/her knowledge about what students need to learn. Therefore, teachers should have an in-depth understanding of the students' development. In this paper, it is exclaimed that teachers should have a thorough knowledge of the subjects they teach as researches show that this is a crucial attribute of highly effective teachers. Teaching Out-of-Field means teaching subject areas outside their field of expertise, which makes it of considerable concern. Hence, it is argued that to improve teaching quality through have quality initial teacher education and select the best candidates to teach children.

\subsection{Out-of-Field Teaching in the Philippines}

In the study conducted by Bayani and Guhao, Jr. (2017) titled "Out-of-Field Teaching: Experiences of Non-Filipino Majors, they accentuated that the phenomenon is present and experienced all schools here in the Philippines. Thus, it is revealed in the study that Out-of-Field teachers experience diverse situations. Furthermore, it is found out that these teachers experience compliance and submission, lack of aptitude for the language, lack of administrative and logistics support, inability to muster enthusiasm and establish rapport, and frustration and insecurity while they are teaching the subject outside their field of expertise. Moreover, the study also revealed the coping mechanism of these teachers while experiencing the phenomenon such as: being resourceful and creative, being diligent and conscientious, making instruction stimulating for students, and being calm and collected. Hence, this study is delimited only in describing non-Filipino Secondary teachers' experiences in Compostela Valley in Out-of-Field teaching.

\section{Methodology}

\subsection{Research Design}

I utilized a qualitative research design in this study. Specifically, I employed phenomenology in this to gain an understanding of underlying reasons, opinions, and motivations. Further, this approach is appropriate, especially when we try to understand people's experiences (Padilla-Diaz, 2015).

I utilized this research design to narrate and understand the teachers' perceptions, perspectives, and understandings of the phenomenon: the out-of-field teaching. In this research, I specifically utilized phenomenology because it focuses more on experiences, beliefs, events, and occurrences with or without regard for the external and physical reality. I believed that this design is appropriate to the study because, according to the Qualitative Research Consultants Association, qualitative research is suited to tasks that aim to study reactions, generate ideas, and understand perceptions. Moreover, Manen and Adams (2010) asserted that phenomenology is used and believed to be appropriate in this study because it prioritizes and investigates individuals' lived experiences about a phenomenon. 


\subsection{Research Participants}

The participants of this study were Out-of-Field teachers who are teaching subjects out of their field of expertise. The research participants were identified through purposive sampling. The researcher selected the participants from the tertiary level leading any issue out of their area of expertise. The researcher had ten (10) participants for this study, as suggested by Cresswell (1998) as cited by Omona (2013).

\subsection{Data Sources}

The out-of-field teachers teaching for three months or below are the sources of information in the study. Through them, the researcher determined different views, comments, opinions, and efforts exerted by teachers as they experience out-of-field teaching. Through this, the research was able to see the difference in their lived experiences about the phenomenon. The information from the research participants' exact location was gathered through audio-recorded in-depth interviews and focus group discussion. Hence, I solicited their experiences about the said phenomenon. The collected data provided enough information needed to make the study valid.

\subsection{Data Collection Procedure}

In any study, procedures are followed to ensure accurate results throughout the study. As the researcher, I am aware of the steps in data collection. So, the following actions were taken to successfully carry out productive results: Firstly, the participants were identified based on the subjects they handle, which are out of their field. The researcher sought help from the program heads after a letter of approval was sent and approved. From then, teachers/lecturers asked if they are teaching subjects outside their field. Secondly, the participants were informed about the study on out-of-field teaching and were requested to sign a consent letter to document their voluntary participation in the study. Thirdly, they were oriented individually regarding the core purpose of the study. Fourthly, the materials needed for the study were prepared that included interview guides and an audio recorder. Fifthly, an in-depth interview followed, and audio-recorded responses of the participants were transcribed to provide thorough information about out-of-field teachers' lived experiences. I collected the data in this study through an individual in-depth interview and focus group discussion. The purpose of this was to explore the participants' experiences on out-of-field teaching. The researcher personally conducted the face-to-face interview to collect significant pieces of information from the participants. All useful questions were included in the interview guide, so we will not miss information. Before this questionnaire was administered, this was validated by the experts.

Furthermore, interviews were accurately documented through an audio recorder and were ensured with safekeeping. Thus, indepth interviews and focus group discussion was useful for gathering participants' perspectives. They were also appropriate for getting peoples' personal feelings, opinions, and lived experiences (Mack et al., 2005). Creswell et al. (2007) emphasized that gathered data should be stored to be easily accessed and protected. Thus, in this study, participants' recorded and transcribed audio responses were saved in a CD format.

\subsection{Data Analysis}

After collection, the data gathered during the focus group discussion and in-depth interviews were summarized, transcribed, translated, and analyzed. In this study, data were firstly organized and prepared for analysis. This involves transcribing interviews, optically scanning material, typing up field notes, or sorting and arranging the data into different types depending on the information sources. Secondly, the data were read thoroughly. I gained a general sense from the information and reflected the overall meaning. Thirdly, I conducted an analysis based on the specific theoretical approach and method used in this study. This involved the coding or organizing related segments of data into categories. Fourthly, I generated a description of the setting or people and identified themes from the coding.

Moreover, I searched for theme connections and represented the data within a research report. Lastly, I interpreted the larger meaning of the data. After thorough analysis, I classified and categorized the data carefully in which the themes of the findings of the study emerged with the core ideas. After transcription, I proceeded to the analysis since the purpose of the study was to explore and understand the lived experiences of out-of-field teachers and identify their efforts as to the phenomenon they experienced. Furthermore, results were documented and analyzed based on the theory used. Central themes were extracted, explained, and written under each topic with relevant citations supporting these themes.

\section{Results and Discussion}

There were ten (10) participants of this study who are from the same school. The participants were divided into two (2) types of data gathering method. The researcher gathered six (6) teachers to participate in focus group discussion and four (4) teachers to participate in in-depth discussion. The participants are currently teaching subjects out of their field of expertise for three (3) months and above. In this phenomenological study, interview transcripts served as primary source of data and structured faceto-face in-depth and focus group discussion questionnaires containing substantial open comments. 
Table 1: Major Themes and Core Ideas of the Lived Experiences of Out-of-Field Teachers

\begin{tabular}{|c|c|}
\hline Major Themes & Core Ideas \\
\hline Challenging & $\begin{array}{l}\text { - Teachers are having difficulty in teaching } \\
\text { something they are not aware of. } \\
\text { - Teachers prepare a lot when teaching out-of- } \\
\text { field subjects. } \\
\text { - Teachers are challenged because they are new in } \\
\text { this field of work. } \\
\text { - Teachers are having difficulty because it requires } \\
\text { them to read and research about the subject. }\end{array}$ \\
\hline $\begin{array}{l}\text { Difficulty in Adjusting to the Academic Content of the } \\
\text { Subject }\end{array}$ & 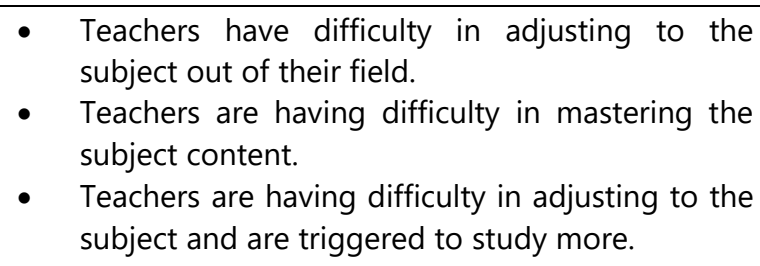 \\
\hline Difficulty in Addressing Students' Queries & $\begin{array}{l}\text { - Teachers can't address the queries of students } \\
\text { about a topic. } \\
\text { - Teachers are having difficulty in addressing } \\
\text { students' questions. } \\
\text { - Teachers were usually not able to properly } \\
\text { address the intellectual students' inquiries. } \\
\text { - Teachers are handling subjects out of their field } \\
\text { so they are having difficulty in answering the } \\
\text { questions of their students. } \\
\text { - Teachers can't answer the questions of students } \\
\text { if they can't prepare for the lesson of the day. }\end{array}$ \\
\hline Difficulty in Establishing Authority & $\begin{array}{l}\text { - Students won't listen because of their mind set is } \\
\text { that their teacher is not an expert and with their } \\
\text { close age gaps. } \\
\text { - Teachers are having difficulty in handling their } \\
\text { students since they are teaching subjects outside } \\
\text { their field of expertise. }\end{array}$ \\
\hline Difficulty in employing Appropriate Teaching Approaches & $\begin{array}{l}\text { - Teachers are having difficulty in applying } \\
\text { approaches to teaching because they are not a } \\
\text { graduate of teacher education. } \\
\text { - Teachers are having difficulty in teaching since } \\
\text { teaching college students is different from } \\
\text { teaching elementary students. }\end{array}$ \\
\hline
\end{tabular}

Table 1 shows the major themes and core ideas of the experiences of out-of-field teachers. As I analyzed the responses of the participants about their experiences as Out-of-Field teachers, five (5) major themes emerged. They are the following: challenging, difficulty in adjusting to the academic content of the subject, difficulty in addressing students' queries, difficulty in establishing authority and difficulty in employing appropriate teaching approaches.

Furthermore, in the table above, participants expressed that teaching Out-of-Field subjects is challenging particularly when they are not mindful about the subject because they have to prepare a lot as they teach the subjects. Most especially, if they are new in this field of work, it requires extensive reading and research about the subject. Then, teachers also experienced difficulty in adjusting to the academic content of the subject chiefly if students are older. Because of that, teachers are triggered to study more. Teachers are experiencing difficulty in addressing students' queries especially if they could not prepare for the lesson of 
the day. Participants are also experiencing difficulty in establishing authority because of students' mind-set that they are not experts of the subject and also of their close age gaps. Lastly, participants are experiencing difficulty in employing appropriate teaching approaches since some of them are not graduates of teacher education program and subsequently others are having difficulty in teaching since teaching college students is different from teaching elementary students.

\subsection{Challenging}

The participants argued that they are challenged as they teach subjects outside their field of expertise.

This concept is linked to the response of participant coded as IDI 1,

"Medyo nalisdan jud siya sir. Kay you need to study further in which wala nimo may mga topic or mga topics na hindi mo napag-aralan during your time. So more on research siyempre mahirap din yon kasi kapag kulang ka ng kaalaman, 'pag may katanungan sila so nahihirapan ka din. Challenge din yun as a teacher."

(It is really hard because you need to study further since there are topics that you were not able to learn before. You have to research because if you don't know the subject, if there were questions, you will have a hard time answering these questions. It is challenging for you as a teacher.)

The presence of this phenomenon in the school I was assigned leads me to conduct the study. Furthermore, it is found out that participants are challenged as they teach subjects out of their field of expertise because they need to prepare a whole heap.

Participant coded as IDI 2 argued that,

"For example elementary ka nga teacher tapos magtudlo ka ug Literature subject tapos sa prof.ed is wala na siya na focus kay gamay lang ang ginatackle during sa college years tapos basta dako kayo siya ug preparation before ka mo enter sa classroom compared nimo

sa kanang elementary nga teaching kay didto nahibal-an ang mga strategies sa pagtudlo sa dili tanan natun-an during sa college years maapply nato sa real-life setting especially Out-of-Field teacher ta"

(For example, you are an elementary teacher then you are going to teach Literature subject and in your Professional education subject, the topic was not given with enough emphasis because it was not discussed thoroughly during college. It needs extensive preparation before you enter the classroom compared to teaching in elementary because it where you learned to apply strategies in teaching. Not all we learned in college will be applied in real-life setting because we are Out-ofField teachers.)

In relation to this concept, participant coded as IDI 3 shared that,

"Ah kadto akong ganina, first maglisod jud ka tungod kay wala paka kabalo kung unsay dagan ana nga subject labi pa ug kanang first time nimo siya nga ma itudlo murag kuan jud kayo kulbaan pud ka kay kuan man siya kanang kailangan gud nimo mag study kailangan nimo na ah magprepare jud ka. Kailangan nimo magbuhat ka ug assignment for yourself para next day naa pud kay ika share ikatudlo ana siya."

(Just like what I've said earlier, at first it is really challenging because you do not know the subject, most especially if you are teaching the subject for the first time. You get nervous because you have to study first. You have to prepare. You have to give yourself an assignment you can share for the next day's lesson.)

Participant coded as FGD 3 added that,

"So as a teacher, ipakita gyud nimo ang kadtong boundaries" "Magconduct ka ug research or study etc. kay para ma aside nga na address nimo tong ilahang learning needs or ilahang skills ma develop" 
(As a teacher, you have to define limitations. You conduct research or study so you can address the learning need of students and their skills will be developed.)

\subsection{Difficulty in Adjusting to the Academic Content of the Subject}

Aside from it is challenging, I found out that participants are also experiencing difficulty in adjusting to the academic content of the subject.

This is aligned to the idea of participant coded as IDI 2 who argued that,

"Being an Out-of-Field teacher kailangan lang jud siya ug dako nga adjustment especially kung dili jud nimo field imong gitudluan."

(Being Out-of-Field teacher requires a big adjustment especially because the subjects you are teaching are outside your field of expertise.)

Participant coded as IDI 3 also added that,

"Ah bagohan! Nachallenge! Ah medyo naglisod jud kay dili man nimo siya kuan field of expertise. Then, at first mangapa jud ka. Siyempre w aka kabalo unsa inomg itudlo diba?"

(I am a neophyte and I am challenged. It is quite difficult because I am not an expert of what I am teaching. At first, you really have to adjust because you don't know the subject.)

Participant coded as IDI 4 verbalized that,

"Actually there's a difficulty and in there is a lot of difficulty as an out-of-field teacher so since it is not my specialization and of course the content of the subject matter we are not familiarize with certain discussion so we make sure that we have a knowledge not thorough but at least we have basic knowledge with regards to the topic of the day."

(Being an Out-of-Field teacher is really difficult since you are teaching subjects out of your field of specialization. The content of the subject is unfamiliar to you. So we make sure to gain basic knowledge about the subject.)

\subsection{Difficulty in Addressing Students' Queries}

One major theme that emerged in this study is that Out-of-Field teachers are experiencing difficulty in addressing the queries of students since they are not experts of what they are teaching.

This is linked to the concept of participant coded as IDI 1 when she said that,

"I have a lot of unforgettable experience sir. So one of that experiences na hindi ko malimutan is my students asked me about yon sa Psychology. So, tinanong niya ako tapos kahit na konting detalye hindi ko maibigay sa kanya yong konkritong snong tawag nito explanation. Kaya sinabi ko sa kanya bigyan mo ako ng panahon at magrereearch ako at sasagutin ko yong tanong na pagdating natin sa kinabukasan"

(I have a lot of unforgettable experience. One of these experiences is when my students asked me about Psychology. They asked me about it and I wasn't able to give a concrete explanation. So, I told them to give me time to research and I will give the answer the next day.)

In relation to this concept, participant coded as IDI 2 emphasized that,

"Kanang mangutana ang estudyante ug mga complicated na questions wherein wala nimo siya nastudyhan kay tungod dili nimo siya field nga naghatag ka ug focus ana kay kung unsa ang naa sa book dira lang man jud ka magfocus. Naay mga unexpected questions nga dili nimo, ikaw mismo teacher dili nimo matubag" 
(When your students ask you complicated questions you were not able to study because you did not mind it since you only consider what is in the book. Then suddenly, there were unexpected questions that even you, their teacher, were not able to answer.)

This concept was supported by participant coded as FGD 2 when she argued that,

"So for me no during my Psychology, Psychology jud ang akong pinakanalisdan sa tanan nakong nahandle na subject because of the different medical terms nga ginagamit and then dili kayo ko hawod sa Science or whatever. So dili man jud maiwasan nga naa juy mga estudyante nga siguro mas bright ba or nagpa-bright bright. Ana gud sir, nakabalo na sila daan unya sukit-sukiton ka ug pangutana sir ba. Then kabalo ka nga nakasabot na siya pero gusto niya nga iya pa ipa deepen pa jud ang explanation. Tapos mangutana siya ug out of topic, ma feel nimo nga wala jud ko kabalo ani sir. Didtoa pa lang makabalo nakp, ah kailangan najud siguro nako mag research"

(For me, during my Psychology, Psychology is really difficult for me because of its medical terms. And, I am not good with it. There will be times students ask you about something they already know just to check your knowledge about it. You knew they know but they just want a thorough explanation. They asked you questions then you can tell that you really don't know it. You can say to yourself you have to research.)

This concept is also seen in the response of participant coded as FGD 4 when he said that,

"When you enter the classroom na wala jud ka kabalo-an ba gani unsa ng mga musical na mga terms. Unya mag-ask ang mga students sa imoha. Lisod jud kayo"

(When you enter the classroom without any background about musical terms, then your students will ask you, it is really hard.)

Participant coded as IDI 3 added that,

"Naa for example ah ang problema pagka dili man gud nimo field nga subject is kanang for example mo wala ka prepare tapos pangutan-on ka sa estudyante ang problema dinha is unsaon nimo pagpalusot unsaon nimo pag-explain sa estudyante nga for example wala jud ka kabalo wala jud kay idea ba unsa imong itubag sa iyaha so mamroblema ka karon kung unsaon nimo ang imuhang estudyante nga masatisfy sa imong tubag bisag wala ka kahibalo so mao na siya'y mangita ka diraag palusot.com."

(The problem in teaching subjects outside your field of expertise is when you are not prepared with your lesson and your students will ask you then you can't answer their questions. You can't explain the answer well to the student. You are having a hard time in finding the correct answer that will satisfy your students.)

\subsection{Difficulty in Establishing Authority}

Another theme that emerged is that Out-of-Field teachers are having difficulty in establishing authority because of their questionable subject expertise and close age gaps.

This is linked to the concept of participant coded as FGD 2 when she said that,

"Kung ma feel na nimo na ang nature sa imong lecture is that boring na kayo kay lisod man pud gud mag sige ta ug lecture unya pagkahuman ang atong estudyante dagko na. Dili pud na sila tanan maminaw sa imuha kay naa pud ang authority ug ilahang kompyansa na katuuhan ba kaha ni si teaher especially sa amo nga murag kaedad lang namo ang mga estudyante pero in teaching techniques, mga ingun ana"

(When you can feel that your lecture has become boring and it is hard to always have lectures because when your students are already mature they have issues with authority whether they are going to believe you or not especially with us that we have close age gaps.)

In relation to this concept, participant coded as FGD 5 argued that, 
"Naa pud juy dili jud mo ana nga naa juy estudyante na kanang dili, maminaw man pero kanang mura ganing ug ganing ipakita jud niya na mas kabalo siya kontra sa imuha diba? Naa juy ing-ana nga estudyante nga kanang mag sige'g pangutana pero pagka the end pud sa topic muhilom ra pud siya"

(There are students who really would not listen. They would insist that they know better. There are students like that. They always ask question and later, they become still.)

\subsection{Difficulty in Employing Appropriate Teaching Approaches}

Another theme emerged from the experiences of Out-of-Field teachers is difficulty in employing appropriate teaching approaches because some of the participants are not graduates of teacher education program and are Elementary Education graduates.

This concept is seen in the response of participant coded as FGD 5 who emphasized that,

"As per experience gihapon as an Agriculturist, dili man gyud ni ingon na kanang maestra jud no so kanang maghandle ug kanang mga social study nga subject unya ang handelan is kanang Criminology so at first lahi, maglisod jud.

(My experience as an Agriculturist, I am not a teacher by profession. So when I handled social studies with Criminology students, I really had a hard time.)

Participant coded as FGD 6 argued that,

"So it is very difficult for me as an Out-of-Field teacher because ah the approach that we have practiced in our college years is the approach for the children and then now we are am handling college students in which they are very naughty sometimes."

(It is very difficult for me as an Out-of-Field teacher because the approach that we have practiced in our college years is the approach for the children and then, now we are handling college students in which they are very naughty sometimes.)

Being an Out-of-Field teacher is really challenging because it requires laborious efforts that would compensate the problem faced by these teachers. Although this is the issue, they also argued that it is fulfilling on the part of the teacher to see that the students are learning. Furthermore, one of the participants added that, despite the challenges these teachers are experiencing, all they have to do is to love what they are doing.

Table 2: Major Themes and Core Ideas on Ways of Coping with the Difficulties and Challenging Experiences of Out-ofField Teaching

\begin{tabular}{|c|c|}
\hline Major Themes & Core Ideas \\
\hline $\begin{array}{l}\text { Careful } \\
\text { Planning of the Subject Content }\end{array}$ & $\begin{array}{l}\text { - Teachers have syllabus. } \\
\text { - Teachers prepare a course outline that will } \\
\text { be the basis of their activities inside the } \\
\text { classroom. } \\
\text { - Teachers carefully plan and read ahead of } \\
\text { time. } \\
\text { - Teachers should plan the lesson through } \\
\text { syllabus. }\end{array}$ \\
\hline & $\begin{array}{l}\text { - Teachers utilize variety/different strategies } \\
\text { like reciprocal teaching. } \\
\text { - Teachers use other forms of strategies and } \\
\text { approaches that best suit the students. } \\
\text { - Teachers employ participatory approach. }\end{array}$ \\
\hline
\end{tabular}




\begin{tabular}{|c|c|}
\hline Employment of Varied Teaching Approaches and Strategies & $\begin{array}{l}\text { - The teacher used seminar workshop in which } \\
\text { students have to perform. }\end{array}$ \\
\hline Engaging with Professional Development & $\begin{array}{l}\text { - Teachers suggest not settling for mediocrity. } \\
\text { They should aim for higher education. } \\
\text { - Teachers engage in advance reading and } \\
\text { research. } \\
\text { - Teachers conduct research about the subject } \\
\text { they are teaching. }\end{array}$ \\
\hline Peer Mentoring & $\begin{array}{l}\text { - Teachers consult their colleagues who have } \\
\text { taught the subject for many years. } \\
\text { - Teachers seek other teachers' help for } \\
\text { support and believed that they can also learn } \\
\text { from others. }\end{array}$ \\
\hline Evaluating/Monitoring of Learners' Development & $\begin{array}{l}\text { - Teachers evaluate the learners whether the } \\
\text { strategies employed are effective. } \\
\text { - Teachers assess them during lectures based } \\
\text { on what they have in mind. } \\
\text { - When conducting practicum, teachers make } \\
\text { sure rubrics are distributed ahead of time. }\end{array}$ \\
\hline
\end{tabular}

Table 2 shows the ways of coping with the difficulties and challenging experiences of out-of-field teachers. As I analyzed the responses of the participants about their ways of coping with the difficulties and challenging experiences of Out-of-Field teaching, five (5) major themes emerged. They are the following: careful planning of the subject content, employment of varied teaching approaches and strategies, engaging with professional development, peer mentoring and evaluation/monitoring of learners 'development.

In the table above, participants articulated their ways of coping with the difficulties and challenges of out-of-field teaching especially in careful planning of the subject content wherein they commonly refer to syllabi making and planning ahead of time. The employment of varied teaching approaches and strategies that best suit the students' nature and capacity is very important. In their pursuit of finding what approach and strategy suit best to their student, it is seen that they also engaged in professional development as they do advance reading and extensive research. Furthermore, because they are not an expert of what they are teaching, it was found out that they also sought support from their proficient equals. To find out whether students learned from them, participant also performed evaluation or monitoring of learners' development.

\subsection{Careful Planning of the Subject Content}

Being an Out-of-Field teacher requires effort and planning to alleviate the challenges along the course of instruction.

This concept is seen from response of participant coded as IDI 1 when she argued that,

"At first may tinatawag tayong syllabi sir. Doon tinitingnan mo kung ano yong ituturo mo . titingnan mo din, ipaplano mo din kung ano yong pwede mong strategy during sa lesson mo.

(At first, we have this so called syllabus. Included in the syllabi are the things you teach. You also plan and assure the strategies to be used in your lesson.)

Participant coded as IDI 2 added that,

"So naa mi'y ginabuhat before conducting na ginatudlo sa among program head sa amoa nga syllabus. So sa syllabus palang daan kadto na ang basehan sa amoang pasunod na klase or kung sa elementary ginatawag na siya ug lesson plan"

(We are preparing syllabi before conducting our instruction which our program required. Your syllabi are the basis of your instructional stream. For elementary, it is called lesson plan.)

Participant coded as IDI 3 also emphasized that, 
"Oh naa jud siya'y plano aside from sa kanang syllabus na pagsunod naay advance or kanang mga other unsay tawag ana ginadugang nimo ba for example mag basa ka ug mga books or asa ka magkuha'g ah other materials or instructional material.

(We have plans but aside from following the syllabus we can also add revisions and add other material or instructional materials.)

This concept is also seen in the response of participant coded as IDI 4 who argued that,

"In planning the lesson, it's in the syllabus itself. Naa nana siya sa syllabus daan in the syllabus for your preliminary midterm upto finals. So, naa na didto tanan han-ay na. Ginahimo jud namo na siya prior to the semester so kailangan before the semester starts the syllabus is intact. So, the content of the subject matter is there so together with the strategies and the methods that you are going to use."

(Planning the lesson is all in the syllabus. We really make our syllabus and it is needed before the semester starts.)

\subsection{Employment of Varied Teaching Approaches and Strategies}

One major theme emerged as participants cope with difficulties and challenges as Out-of-Field teachers is the employment of varied teaching approaches and strategies.

Participant coded as IDI 1 said that,

"One of the strategies na akong gïngun is reporting, So effective siya it is because ang bata is maningkamot siya nga mahibal-an ang iyahang topic ug sa iyang lesson. It is because pag naay question sir sa iyang classmate makatubag siya mismo"

(One of the strategies I said was reporting. It was effective because the students will really strive learning the lesson. And when someone asks him, he can answer.)

This is supported by participant coded as FGD 5 who said that,

"Okay sa amua pud ah sa among klase is usually dili pud ko musugot na the students is not kanang using participatory approach. So naa jud ang participatory approach through interactive discussion so while I am lecturing them after that ah follow up question classification suggestions and additional ideas then after that ah doing such activity which is connected to the topic so ingon ana ang flow."

(In my class I encourage my students to participate and interact because I am using participatory approach. There are follow up questions every after lecture.)

This is supported by participant coded as FGD 6 when she shared that,

"In my seminar-workshop sir, it is effective because there are two approaches I have employed which is independent learning and discovery approach"

(In my seminar-workshop, it is effective because there were two approaches I have employed which are independent learning and discovery approach.)

Moreover, participant coded as IDI 4 shared that,

"Included in the syllabus is the strategies of learning. Okay, so if ever along the way in your ahm teaching naa kay mga encounter na dili effective ang strategy nga naa sa imong course syllabi you are going to use another strategy for them to learn. Mao na siya akong ginabuhat tanan nako nga dili effective ang akong strategy sa akong course syllabi mag try ko ug another strategy nga para mag fit in sa ilang learning capabilities" 
(Included in the syllabus are the strategies of learning. If you can encounter anything along the course of your instruction like your strategies indicated in the syllabus are no longer effective, use another strategy for them to learn. I do this every time I see that my strategies are no longer effective. I try other strategies that suit best to students' learning capabilities.)

\subsection{Engaging with Professional Development}

Another theme that emerged is the engagement of teachers with professional development. Learning is a continuous process. Teachers need to embrace changes to improve efficacy.

This concept is seen from participant coded as IDI 1 when she said that,

"Dapat dili ta stagnant sa atong nahibal-an. Dapat as a teacher naa paman tay professional growth kinahanglan mustep-up pa ta ana. Dili kay dinhia lang ta taman. For example graduate na ta ug BEEd ah dihaa lang ta taman. So naa pamay masteral doctoral if possible para pud sir pinaage ana nga MAEE or masteral mas madagdagan pa ang imong nahibal-an"

(We should not be motionless in what we know. As a teacher, we should step-up and engage into professional growth. Don't just end up there. For example, you are a graduate of Bachelor in Elementary Education, you end up there. We have master's degree and doctorate degree. With that, you can learn more.)

Participant coded as FGD 3 also expressed that,

"Okay so for me so I have experienced difficulties particularly for the subjects out of my expertise. So in that way so kahit na maka experience tayo ng mga kaunting difficulties pero it is not, it doesn't mean na wala na tayong gagawin. So as a teacher, we should do both our efforts in order to address the learning needs of our students in the sense na that is our goal, why are we here in the institution,diba? That is why so edouble ang effort then conduct more research and study kung maari mas mabuti na pwede hindi na tayo matutulog para lang ma address ang learning needs sa imong students.

(For me, I have experienced difficulties particularly for the subjects out of my expertise. In that way, even if we experience difficulties, it doesn't mean you won't do anything. As a teacher, we should do both our efforts in order to address the learning needs of our students in the sense that it is our goal why we are here in the institution. We need to double our efforts and conduct research and study more. We have to break a leg just to address the learning needs of our students.)

This concept is also validated by participant coded as IDI 4 when she said that,

"I have am I have a problem,dili,peace, in terms of its specialty or the specialization of the subject matter. So that is why I am trying to address these difficulties in the form of reading such references that is nga naa na assign sa ako nga course or subject"

(I have a problem in terms of expertise to the subject I teach and I am trying to address it in the form of reading references of the subjects assigned to me.)

\subsection{Peer Mentoring}

Moreover, another theme emerged from the study was about participants seeking experts help for self-improvement. Peer mentoring is one of the ways of coping cited by the participants.

This notion is seen in the response of participant coded as IDI 2 who stated that,

"So mao to siya naka experience naman ko ug ing ato so usahay mangutana ko sa mga teacher pud na nakaagi na ani tapos didto ko mangutana sa ilaha tapos nagabasa ko ug mga books. Then mangutana ko sa uban pa na mga tao kung kabalo ba sila about ani nga topic. Daga pangutana jud ko sir kay lisod man pud ug dili ko mangutana kay ako mismo wa man pud ko nangutana" 
(Because of my bad experiences, I now consult my fellow teachers who have previously taught the subjects I am teaching. I also read books. I ask questions from other people if they know something about the topic. I really ask questions because it's hard if I would not.)

This was supported by participant coded as IDI 1 when she said that,

"Siyempre mas makalearn man ka if dili lang sa imong sariling paningkamot mas makalearn man ka if dili lang sa sarili nimong paningkamot mas makalearn man ka sa laing tao"

(Of course you can learn more if you don't rely solely to yourself. You can also learn a lot from others.)

\subsection{Evaluating/Monitoring of Learner's Development}

Lastly, in view of the teachers desire to assure learning, another theme emerged which is focused on evaluation or monitoring learners' development.

This impression is realized as participant coded as IDI 4 supposed that,

"Okay so what are the tools to prove that your strategies is effective or not, through evaluation. You have to evaluate your learners if that certain strategy is effective of course you have to do your part. You have to do your part. You have to try your best to explain it clearly kay dili man siya effective ang imong strategy kung ikaw mismo sa imong kaugalingon di ka masbtan magtudlo." "You have to assess them para imo siyang makita kung effective ba or dili"

(What are the tools to prove that your strategies is effective or not, through evaluation. You have to evaluate your learners if that certain strategy is effective. Of course you have to do your part. You have to try your best to explain it clearly. If they couldn't understand you, your strategies are not effective. You have to assess them so you would know if your strategies are effective or not.)

This notion was supported by participant coded as FGD 1 as he said that,

"I incorporated language ah I mean communicative approach in my teaching" "So what I did is that ah I focused more on the speaking part of the students or communication part of the students in my subject rather than paper-and-pencil test exams" "We socialize with others and communicative approach was effective on my part because my learners were able to express what they have learned through that particular approach. I can assess them during my lectures or my class time not just through quizzes and exams. I can assess them every day whether they're learning or not because they are truly expressing what they have in mind"

(I incorporated communicative approach in my teaching. What I did is that I focused more on the speaking part of the students or communication part of the students in my subject rather than paper-and-pencil test exams. We socialize with others and communicative approach was effective on my part because my learners were able to express what they have learned through that particular approach. I can assess them during my lectures or my class time not just through quizzes and exams. I can assess them every day whether they're learning or not because they are truly expressing what they have in mind.)

Participant coded as FGD 4 added that,

"In my HELE subject I used performance-based or practicum. And also, I before I before na dili pa ko mag instruct sa ila is ginahatag nao ang rubrics. So di jud ta dapat makalimot ana kay on how to assess the performance of the students na para makabalo sila kung asa sila lamang or asa pud sila baba.

(In my HELE subject, I used performance-based or practicum. Before I instruct my student, I give them the rubrics because through that they can also assess themselves with regards to their strength and weakness.) 
While there are many challenges along the way, we can always find solutions to these challenges. The participants have spoken and shared their ways of coping with the challenges they encountered. Above all, their concern to their students and work prevailed.

Table 3: Major Themes and Core Ideas of the Suggestions of the Participants to Out-of-Field Teachers

\begin{tabular}{|c|c|}
\hline Major Themes & Core Ideas \\
\hline Continuing Professional Development & $\begin{array}{l}\text { - Teachers should engage into professional } \\
\text { - } \quad \text { Tevelopment. } \\
\text { - Teachers should conduct study and research. } \\
\text { through professional development. }\end{array}$ \\
\hline Consultation to Experts & $\begin{array}{l}\text { - Seek the help of teachers who are specialized } \\
\text { in these fields or certain subjects. } \\
\text { - Don't hesitate to ask something from other } \\
\text { teachers. }\end{array}$ \\
\hline Hiring of Qualified Teachers & $\begin{array}{l}\text { - The school should hire teachers who will } \\
\text { - } \quad \text { Theach subjects within their field of expertise. } \\
\text { specific field. } \\
\text { - Make sure that when you hire teachers they } \\
\text { are what you are looking for. } \\
\text { - The university or institution must hire } \\
\text { particular teacher for a particular field. } \\
\text { The institution should strongly align the } \\
\text { subjects to the expertise of the teacher. }\end{array}$ \\
\hline Assigning of Relevant subjects to teachers & $\begin{array}{l}\text { - The administration should give/load teachers } \\
\text { subjects that are familiar to them. } \\
\text { - The school should offer subjects according } \\
\text { to the teachers' ability/capacity. } \\
\text { - The distribution of the subjects could be on } \\
\text { the expertise of the teachers. }\end{array}$ \\
\hline
\end{tabular}

Table 3 shows the suggestions of the participants to Out-of-Field teachers. For the participants, it is reflected that teachers are suggesting other Out-of-Field teachers to engage in professional development to purposely improve efficacy. Moreover, they suggest consultation of teachers teaching subjects outside their field of expertise to their competent fellow teachers. Hence, they were also suggesting that institutions should hire qualified teachers emphasizing that teachers should teach based on their field of expertise. Furthermore, assigning of relevant subjects to teachers is encouraged by the participants to be addressed to the administrators of any institution.

\subsection{Continuing Professional Development}

Participants expressed that teachers should develop themselves in terms of their proficiency about the subject. This concept is seen in the response of Participant coded as IDI 1, who said that,

"First siguro sir naa man tay ginatawag na professional development kung saan yong mga instructor or yong mga Out-of-Field teacher is example sa BEEd siyempre pag BEEd alam talaga lahat diba sir? Siguro first, is professional development. Mag-enroll ng masteral if ever. Then, next is seminars or workshops for example or emeeting nimo imong colleague for example asa sila nalisdan"

(We have Professional development wherein Out-of-Field teachers can engage like BEEd graduates. They can enrol to masters and seminars or workshops afterwards.)

This is supported by participant coded as FGD 3 when he said that, 
"In the field of education dili man gyud na malikayan na ah kanang latagaw bitaw tag kanang out sa atong expertise. So as teacher so dili nato limtan ang atong sarili. Pwede nato siya butangan ug boundaries so we'll expand. Then mao to siya, we will conduct more research. Kinahanglan ka nga magstudy. So mag duty para para maaddress tong learning needs sa imong estudyante para at the end naa pud kay ah kanang imong product ba or ang imong ma produce is quality"

(In the field of education, there is a great possibility that you can teach subjects outside your field. We should not forget to improve ourselves and conduct research. We need to study so that we can offer quality teaching.)

Moreover, participant coded as IDI 4 added that,

"After the adjustment period kabalo naka sa imuhang weakness and the strength at that time. So what you have to, you have to improve your weaknesses"

(After adjustment period, you already know your weaknesses and strength. What you have to do is improve.)

\subsection{Consultation to Experts}

Another theme that emerged is Out-of-Field teachers should consult experts about the subject.

This is suggested by participant coded as IDI 1 when she said that,

"If nandoon yong mga katrabaho mo for example if ako nahihirapan talaga ako sa Science nagpapatulong ako sa iyo. Nagpapaturo din ako doon sa mga Biology or mga Science talaga na teacher" "Siguro sir sa akoa as an out-of-Field teacher if naa miy mga subject na dili ko knowledgeable I think I have to ask my colleagues or my co-workers especially those specialized na nila nga mga subjects. Pwede pud siguro sir cooperative teaching for example if ako magtudlo ko ug subject nga related sa Science siguro pwede ko mo tap sa mga Science teachers na pwede mo sulod sa akong klase para sila maka discuss para mas maayo nga sila ang mo discuss kay sila man ang well-known ana"

(Seek help from your colleagues like what I am doing I seek help from you and other teachers teaching Biology or Science. Cooperative teaching can also be utilized wherein I can ask help from Science teachers to enlighten my students about certain topics.)

This was supported by participant coded as IDI 3, who said that,

"Unang una kung naglisod jud ka dili dapat maulaw mangutanan dili ka dapat mag alanganin na mag research ug magtuon para jud dili ka maglisod. Ikaw raman gihapon ang makakuan ana benefit diba? So dili ka magpa as if nga hawd ka nga gipatudlo ka ana nga subject bisag wa gyud ka."

(If you find the subject difficult don't hesitate to ask help. Don't act as if you know everything.)

\subsection{Hiring of Qualified Teachers}

One major theme that emerged is hiring qualified teachers in an institution which is thought to be of inordinate relief in solving disputes of Out-of-Field teaching.

This is seen in the response of participant coded as IDI 2 who suggested that,

"Siguro sir sa institution pa lang daan dapat siguro maghire sila ug is aka teacher kanang field jud niya kay for example sa English nga teacher maghire ka ug English nga teacher unya ang imong ipatudlo sa iyaha field sa English teacher. Katong literature, English ug unsa pa diraa. Di nimo siya ipatudlo ug lahi ang field ang tao. For example Mathematics tapos magtudlo ang Gen.ed na teacher ug Mathematics. Then naa may mga in-depth bisag muingon ka oh hawod siya ug Mathematics pero dili mana niya ingon jud niya na field. So, dili niya ma sustain tong kinahanglan nga info sa mga bata." 
(To the institution, they should hire qualified teachers for a particular subject. English teachers should teach English subjects. For example BEEd-Generalist will teach Mathematics, there are topics in Mathematics especially in-depth lesson which they don't know. They can't sustain the needs of the students about the subject.)

Participant coded as IDI 3 also verbalized that,

"Enough ang teachers for example kanang kung unsa ilahang expertise didto sila kanang kompleto jud sila ba para dili ang kay kulang kulang man gud siya ug mga teachers siyempre kanang dili imuhang kuan maglisod jud ka. Ang epekto pud sa mga bata man gud is dili man pud hawd dang ilahang teacher ana dinhaa nga area"

(There should be enough teachers for a particular subject area because if teachers would teach subjects outside their field they'll experience hardships. Students will be primarily affected.)

This was supported by participant coded as FGD 1 when he said that,

"I believe University/institution must hire particular teacher for a particular field. So how to do this? Very difficult. It is up to the ahmmm"

(I believe University/institution must hire particular teacher for a particular field. So, how to do this? It's very difficult.)

Participant coded as IDI 4 also added that,

"Make it sure pag hire pa lang daan ang specialty niya tugma na didto sa imong ipatudlo or kung naa man gani kay imong mga subordinate ihatag lang nimo nga topic is naa silay background though dili ing-ana ka thorough but naa silay background sa specific nga subject."

(Make it sure when hiring teachers they are suited to one you need. Teachers should have background about the subjects they are going to teach.)

Participant coded as FGD 2 further said that,

"Actually ano na siya sir no lisod na siya nga suggestion. So mag start siya sa kato nga mga panel of interviewers unsa ilang standards when it comes to hiring a teacher whether part time or regular. For example from then mangutana sila sa particular program head para makabalo siya kung unsa diyuy gikinahanglan sa kana na ano ka na institution. Kay for example if ever maghire lang deritso ang atong university or panel of interviewers didtoa, yes maam you are officially hired pero wla sila kabalo ay magtudlo diay ni sila ug Filipino and then English major murag ing-ana gud sir. So sa diraa pa lang daan gikan sa taas padung sa ibabaw nga information na kami nga particular nga teacher dili lang kay pag mangutana man gud na ang interviewer na can you teach this kind of subject Filipino unya English ka ikaw nga job seeker muningon ka yes sir. Dapat naa kay particular nga English nga motudlo jud kung unsa jud iyahang field of expertise"

(These suggestions are hard to achieve in our level because these should start from the panel of interviewers. There should be particular teachers who will teach specific subjects.)

\subsection{Assigning of Relevant Subjects to Teachers}

Another major theme found is that administration must assign relevant subjects to teachers.

This concept is seen from participant coded as IDI 4 who said that,

"For the admin of course ang ako kay jud maikasulti is ang mga applicant gyud muingun gyud silag kasagaran man gud pangutana sa admin like for instance you are a Science a teacher muana man gyud na ang admin nga gusto man gud nila ang versatility or the versatile teacher so ang pangutana gyud ana nila sa HR to be specific muana man gyud na sila, okay you are a Science teacher can you handle Filipino? Can you handle of course as an applicant muana gyud na Yes! Ok kaya nimo ang job and that is for ah kuan na siya what do you call this one kanang ok economiya. 
Sa iyang sa mga applicant mao gyud na iyang itubag. Yes I can handle Math. I can handle Filipino but the point there is, even me kung also ang applicant, Yes I can handle Filipino. Whatever subjects you will give to me pero pag abot ana sa field. Yes you can handle but you are not specialized so mao na siya dapat, make it sure pag hire pa lang daan ang specialty niya tugma na didto sa imong ipatudlo or kung naa man gani kay imong mga subordinate ihatag lang nimo nga topic is naa silay background though dili ing-ana ka thorough but naa silay background sa specific nga subject.

(Administration of any institution should see to it that in the hiring process, hired teachers are properly matched to the subjects they are going to teach. If not possible at least teachers have background about these subjects.)

Participant coded as FGD 1 added that,

"I think this is very broad idea no but I will try my best to suggest this one solving this in opinion will start on the macro level which is the offerings of the subject of course when these subjects have particular teacher"

(My opinion will start on the macro level which is the offerings of the subject of course when these subjects have particular teacher.)

Solving the issue of Out-of-Field teaching would be difficult if everyone in the academe would not support each other in this endeavor. Moreover, this issue requires collaborative efforts of the students, teachers and the administrators. Therefore, all should work as one for the benefit of everybody.

\section{Lived Experiences of Out-of-Field Teachers}

The term Out-of-Field Teaching was used by many in a way that it denotes to those teachers assigned to teach topics which they are not specialized in (Ingersoll and Merril 2011). Furthermore, it is mentioned earlier in this study that there are more out-offield teachers teaching than those who are really experienced (Weldon, 2016).

\subsection{Challenging}

As for the participants, they find teaching outside their field of expertise very challenging. They mentioned that it is problematic because it requires extensive reading and further research. They exclaimed that most of them are new to the subjects they are teaching.

Moreover, they are not aware or equally knowledgeable as to the subject content is concerned. This is roughly determined to be one of their primary concerns. According to Mizzi (2013), teachers teaching outside their specialism area face considerable lesson preparation challenges. This was supported by De Jong et al. (2002), who stated that teachers' knowledge base strongly influences all aspects of teaching like preparation, planning, and decision making regarding the choice of content to be learned. Thus, it is argued that preparing as a teacher is very challenging and difficult as difficult decisions are to be made when crafting the course's structure and content (Calderhead \& Shorrock, 1997).

\subsection{Difficulty in Adjusting to the Academic Content of the Subject}

Secondly, this theme arises when participants emphasized their difficulty in adjusting to the content of the subjects they are teaching. Most of the participants experience difficulty, especially that this is not in line with their expertise. They are having difficulty in mastering the subjects because they themselves do not understand the terms under this umbrella of topics or ideas.

When you are not an expert on what you are teaching, you will have a hard time adjusting. This is seen from Mizzi's (2013) idea that teachers must understand the structure and nature of the discipline and learn to adapt to the unfamiliar content knowledge. Furthermore, he added that the teacher's inadequate background about the subject results in issues in adjusting with the subject and will impact the development of the teachers' pedagogical knowledge, self-confidence, and attitudes when teaching disciples outside their field of expertise.

\subsection{Difficulty in Addressing Students' Queries}

Another theme that emerged is about teachers experiencing problems in addressing students' questions. Teachers uttered that they often fail to address their students' queries about the subjects they are teaching. As they narrated, there were times wherein students know more about the topic than they do, which results in students interrogating them. They further exclaimed that their inability to address students' queries is due to their lack of content knowledge or expertise. Thus, according to Auseon (1995), he 
stated that a teacher's professional knowledge affects all instruction phases: lesson content and planning, implementation, assessment, and reflection. In the art of education, limited knowledge affects the teacher's representation of art, the focus of inquiry and criticism, and the criteria and method for assessment. And, this leads to the inability of the teacher to answer students' questions. Moreover, this was supported by Jadama (2014), who stated that teaching involves imparting knowledge, skills, and attitudes to an individual. It is argued by Montebon (2015) that articulate teachers are proficient in the subjects they teach and are profound in delivering the lessons through their art of teaching.

Furthermore, in the process of teaching, students' doubts and misconceptions should be clarified. However, if the teacher is mainly ignorant or uninformed about a subject matter, can pass false ideas. Therefore, a teacher will find it extremely difficult to answer varied questions from students about a subject matter (Jadama, 2014).

\subsection{Difficulty in Establishing Authority}

The participants shared that they are having difficulty in handling the students' behavior. Since they are Out-of-Field teachers, they are not an expert of what they are teaching. There are times their lectures go boring, one participant shared. They do not have enough knowledge that will contain students' interest along with the discussion. They also shared that when students think or know that you are not an expert on what you are teaching, they will not listen because they tend to question your credibility to establish authority inside the classroom.

This is supported by Thomas's (2014) concept about the Expert Power of a teacher, which refers to the knowledge and experience a teacher brings with them into the classroom. Teachers with this form of power are knowledgeable about the subjects they are teaching and can also express it in a straightforward way to the students. He also added that when students can tell that if you know what you are doing, it gives you, as a teacher, some authority and the right to lead your students because they trust you. When teachers do not know what they are teaching, students may not want to follow them. Furthermore, Weimer (2009) said that students are willing to do as their teacher says if they recognize that they know more than they do.

\subsection{Difficulty in employing Appropriate Teaching Approaches}

As to the participants, they are experiencing difficulty in using teaching approaches inside the classroom. This is happening mostly to those teachers who are not a graduate of teacher education courses. This difficulty occurs when teachers do not have something to apply. The lack of expertise in the subject, including teaching strategies and approaches used to teach the subject, impedes effective teaching, says Kathirveloo, Puteh, and Matematik (2014). Teaching approaches and methods are learned in teacher education programs in any institution that offers this kind of curriculum. Although these can be learned through experience, formal training is still more effective.

\section{Ways of Coping with the Difficulties and Challenging Experiences of Out-of-Field Teaching}

I gathered a lot of ways on how participants cope with the difficulties and challenging experiences as Out-of-Field teachers. They emphasized that one of their ways of coping with the difficulties and challenges they are experiencing is through careful planning of the subject content. For example, the creation of a course outline wherein teachers are guided with the activities in the classroom.

\subsection{Careful Planning of the Subject Content}

The participants emphasized that they make sure that they carefully plan the lesson by formulating their syllabi. One participant added that these syllabi complement the lesson plans of elementary and secondary teachers. Along with these syllabi, they prepare themselves for the conduct of instruction, which includes pedagogical and content knowledge. According to Vellena and de Mesa (2015), instructional planning provides logical sequencing and pacing of lessons. Moreover, he added that this provides teachers sense of direction. Thus, practical teaching will be achieved with careful planning, preparation, and interest in what you are doing (Alanzi, 2019). Hence, when the teacher is clear with what is to be done, the lesson's flow is smooth because all the information has been gathered. Thus, the details have been decided beforehand.

\subsection{Employment of Varied Teaching Approaches and Strategies}

Another concept seen is that participants use varied teaching approaches and strategies to support students in the learning process. Participants mostly use student-centered methods like reciprocal teaching, communicative approach, wherein students are primarily involved in an activity. One participant added that when one strategy is no longer sufficient, she will move on to another method to ensure learning. Brodhagen (2015) argued that for teachers to reinforce the learning, they must learn to apply various teaching strategies. He also emphasized that this will maximize the understanding of the students. According to Levy (2008), as cited by Gentry (2013), educators are mandated to see that all students meet the standards. By using differentiated instructional strategies, educators can meet all students' needs and help them exceed the established criteria. 


\subsection{Engaging with Professional Development}

To address their concerns as Out-of-Field teachers; they engage with professional development to augment the lacking knowledge and skills they have. Furthermore, they emphasized not to settle for mediocrity and engage in research to advance oneself to another height of professionalism. Improving oneself as a teacher is essential because students' needs are changing, and as 21 st-century teachers, we have to adapt to these changes to ensure that students have something to learn from us. When teachers do not improve themselves, students' performance can also be hampered because teachers are the models of these students. When people refer to professional development, they usually mean a formal process such as a conference, seminar, or workshop; collaborative learning. However, according to Mizell (2010), it may occur in an informal setting such as independent reading and research. Moreover, this enables educators to develop the knowledge necessary to address students' learning challenges. He added that what teachers learn from college cannot provide a wide range of expertise to support them in the field. All professionals take many years to gain the knowledge and skills for their roles to be in place. He also exclaimed that educators who do not experience effective professional development do not improve their skills, and student learning suffers.

\subsection{Peer Mentoring}

Another theme that emerged from the participants' ideas is peer mentoring, wherein teachers consult their colleagues who have taught the subjects they are training for the past years. A participant also added that teachers do not learn by themselves; they also learn from others. Nobody is an island. We need each other back to ensure we would not fail our students from their expectations. We need support from other people aside from ourselves. According to Mizell (2010), it is evident that teachers encounter several challenges such as classroom management, instruction, and curriculum and school culture. Moreover, studies show that new teachers who receive intensive mentoring significantly affect student achievement after as little as two years. Hudson (2012) asserted that preparation has always been the concern of a beginning teacher. Thus, a teacher graduating from any institution has the same responsibilities as those who have been teaching for many years. Moreover, he also emphasized that school administrators should be aware of their teachers' needs, especially in helping them get through their period of adjustment. Furthermore, he stressed that beginning teachers should work hand-in-hand with the experienced and seasoned teachers.

\subsection{Evaluating/Monitoring of Learners' Development}

Participants believe that teachers need to evaluate or monitor students' progress to see if strategies used are effective or not. Assessing students' performance will give teachers hints whether they learned from you or not. This will also help teachers improve themselves because of the feedback they can get from its results. Evaluating students' performance is vital because this is one way of knowing whether we have achieved our objectives of the day. Hence, it is argued that assessment is one of the essential aspects of the teaching and learning process. Furthermore, it is emphasized in the study titled "Assessment and Feedback Practices in the English Language Classroom" that assessment and feedback are two of the inseparable aspects of the classroom culture (Rahman et al., 2011).

\section{Suggestions of the Participants to Out-of-Field Teachers}

\subsection{Continuing Professional Development}

Participants are suggesting that teachers should submit themselves to professional development. One of the participants argued that teachers have weaknesses and strengths and what matters most is we keep moving. As discussed previously in this study, continuing professional development is essential for teachers because this keeps them abreast of the changes in students' knowledge and skills. According to Kloosterman (2013), the ultimate outcome of well-planned continuing professional development is that it safeguards the public, the employer, the professional, and the professional's career. She added that professional development ensures the capability of the teacher in pace with the current standards of others in the same field. Hence, this is supported by Collinson (2010) as he emphasized that the improvement of an educational system is dependent on many factors, including the advancement of teachers' skills through continuing professional education. Furthermore, Kloosterman exclaimed that with this, you and your knowledge stay relevant and up-to-date.

\subsection{Consultation to Experts}

Another theme that emerged is that teachers should consult experts of the fields/disciplines they are teaching. They said that when a teacher is having difficulty, they should not hesitate to ask for others' help. It is usual for teachers to teach outside their field of expertise to know everything about these subjects. These experts can help these out-of-field teachers have a deeper understanding of a discipline.

According to Professor Loughran (2011), as a beginning teacher, it is reasonable to seek others about what needs to be done and the best way to do it. Thus, it is mentioned earlier in this study that teachers need support in their first years of teaching (Darling-Hammond,2010; Le Maistre and Pare, 2010). 


\subsection{Hiring of Qualified Teachers}

Out-of-Field teachers experience problems from all directions, from the subject content down to the employment of appropriate teaching approaches and strategies inside the classroom. These out-of-field teachers were suggesting the hiring of qualified teachers who are experts in their fields. These teachers should be encouraged to teach subjects in line with their area of expertise. When teachers know a wide range of knowledge about what they are teaching, they become more effective and efficient because they know what they are teaching. A teacher can't teach something he or she doesn't have. This issue should start with the school administrators as they are the ones who hire teachers to teach. Furthermore, a participant emphasized that enough teachers teaching a specific field should be provided. It is argued by Valenzuela (2019) that competent and qualified teachers are indeed very crucial in any educational institution. Teachers being the prime mover of the educational wheel, play an essential part in achieving the school's vision, mission, and goals. Thus, his study on "Recruitment and Selection Process of Faculty in the Higher Education Institutions in the Philippines" recommended that the schools' recruitment policies should be strictly followed. Further, he emphasized that administrators should take part in improving the recruitment system. Moreover, Glass (2001), as cited by Stronge and Hindman (2006), stated that teachers who are already experienced and experts are more effective with students due to their use of a wider variety of strategies. This is supported by Kathirveloo et al. (2014) in their study on "Effective Teaching: Pedagogical Content Knowledge," in which they found out that there is a powerful relationship between what the teacher knows, how he or she knows it, and what he or she can do on this knowledge in the context of instruction. Therefore, we must also understand the importance of qualified teachers to high-achieving schools. Moreover, Ingersoll (1998) stated that this is precisely why it is crucial to find solutions to the Out-of-Field teaching problem. Thus, it is argued that school administrators must hire quality teachers who are experts in their teaching in order to assist students in reaching their maximum potential.

\subsection{Assigning of Relevant Subjects to Teachers}

Lastly, another theme has emerged, which is all about assigning teachers to their field of expertise. Meaning, teachers will be given subjects in line with their area of specialization. The participants exclaimed that this might be hard. If found impossible, at least institutions will ask and adequately assess these teachers about their capabilities/abilities to assign them to their inclination. The participants were suggesting the need to assign subjects to teachers based on their expertise because when topics are in line with the teachers' expertise, they are more effective (Huizinga et al., 2019). This notion is supported by Haitti (2003) when he identified five major dimensions of excellent teachers, namely: can identify essential representations of the subject, can guide learning through classroom interactions, can monitor learning and provide feedback, can attend to affective attributes, and can influence student outcomes. Furthermore, he explained that experts in their field have more integrated knowledge. They can combine new knowledge with prior experience, which allows them to relate new curriculum across the other.

\section{Conclusion}

This phenomenological study aimed to explore and understand the lived experiences and struggles of Out-of-Field teachers. Thus, in this research it is discussed that subject matter knowledge is essential in the teaching-learning process. Although teaching is not all about imparting the subject's content, it could significantly affect the students' learning. Being an expert on what you teach has a wide array of effects on the teaching-learning process. If one is an expert, he/she can explain the subject; clearly, he/she can answer the questions of the students and will lessen his/her workload as a teacher as he/she will have little adjustment as to the subject matter is concerned. Moreover, it is argued in this study that expert teachers are more effective than beginning teachers. The foremost concern of the teaching profession is the way teachers transfer the knowledge. If the teachers are experts in the field they are teaching, they have a deep understanding of the subject, enabling them to impart the knowledge in a more exact and more accurate form of explanation. This implies that teachers must be proficient in what they are teaching. Teachers impart knowledge to students who believe that it is right. Most of the time, students ask questions, and when the teacher is well aware of the subject matter, he/she is teaching, he/she can answer. However, in a case where teachers are not experts in what they teach, they should solve their issues with content knowledge. Teachers should engage in professional development where they could improve themselves professionally. Teachers are the leading agents of the educational wheel. Therefore, they must equip themselves with in-depth knowledge about the subjects they teach.

With the results of this study, other researchers may study further the experiences of Out-of-Field teachers. Many of us still do not understand the experiences of these teachers. The fact that it is still occurring makes it unattended or ignored. Moreover, this study is all about Out-of-Field teachers' experiences, but future researchers could broaden this study and focus more on the solution to this phenomenon.

Additionally, in this study, the researcher utilized phenomenological qualitative study. However, future researchers may conduct quantitative research about the phenomenon, which will be all about the ratio of Out-of-Field teachers to In-Field teachers to trace the severity of the problem. Furthermore, future researchers may also conduct a study about the underlying causes of Outof-Field teaching and possible solutions to this problem. 


\section{References}

[1] Alanazi, M. H. (2019). A Study of the Pre-Service Trainee Teachers Problems in Designing Lesson Plans. Arab World English Journal (AWEJ), 10(1), 166-182. https://awej.org/images/Volume10Number1March2019/15.pdf

[2] Auseon, J. (1995). The Role of Pedagogical and Subject Matter Knowledge in Preservice Art Teaching. Marilyn Zurmuehlen Working Papers in Art Education, 13(1), 54-68. https://doi.org/10.17077/2326-7070.1276

[3] Bayani, R., \& Guhao Jr., E. (2017). Out-of-Field Teaching: Experiences of Non-Filipino Majors. International Journal of Education, Development, Society and Technology, 5(11), 91-127. https://zenodo.org/record/1423235\#.YAr10OgzblU

[4] Brodhagen, B. L. (1998). Varied Teaching and Learning Approaches. Middle School Journal, 29(3), 49-52. https://doi.org/10.1080/00940771.1998.11494507

[5] Calderhead, J., \& Shorrock, S. B. (1997). Understanding Teacher Education: Case Studies in the Professional Development of Beginning Teachers. Graphicraft Typesetter Ltd., Hongkong.

https://books.google.com.ph/books?hl=en\&lr=\&id=7VI5I8LIwLsC\&oi=fnd\&pg=PP9\&dq=why+beginning +college+teachers +have +difficulti es\&ots=QKPApDWeNG\&sig=W9rLC2c4e36KLTDIUvKoZ2cuzl\&redir_esc=y\#v=onepage \&q=why\%20beginning\%20college\%20teachers\%20have\%20difficulties\&f=false

[6] Cinkir, S., \& Kurum, G. (2015). Discrepancy in teacher employment: The problem of out-of-field teacher employment. The Journal of the International Society for Educational Planning, 22(1), 29-48. https://files.eric.ed.gov/fulltext/EJ1208556.pdf

[7] Collinson, V., Kozina, E., Kate Lin, Y. -. H., Ling, L., Matheson, I., Newcombe, L., \& Zogla, I. (2009). Professional development for teachers: a world of change. European Journal of Teacher Education, 32(1), 3-19. https://doi.org/10.1080/02619760802553022

[8] De Jong, O., Veal, W. R., \& Van Driel, J. H. (2002). Exploring Chemistry Teachers' Knowledge Base. In Chemical Education: Towards Researchbased Practice (pp. 369-390). Dordrecht: Kluwer Academic. https://doi.org/10.1007/0-306-47977-X_16

[9] Demombynes, G. (2018, July). Assessing basic education service delivery in the Philippines: Highlights from findings regarding teachers. Www.Deped.Gov.Ph. https://www.deped.gov.ph/wp-content/uploads/2018/07/Philippines-PETS-QSDS-teachers-for-education-summitv2.pdf

[10] du Plessis, A. E. (2015). Effective education: Conceptualising the meaning of out-of-field teaching practices for teachers, teacher quality and school leaders. International Journal of Educational Research, 72, 89-102. https://doi.org/10.1016/j.ijer.2015.05.005

[11] Fabrice Henard \& Deborah Roseveare. (2012). Fostering Quality Teaching in Higher Education: Policies and Practices. Organisation for Economic Co-operation and Development.

[12] Gentry, R., Sallie, A., \& Sanders, C. (2013). Differentiated Instructional Strategies to Accommodate Students with Varying Needs and Learning Styles. ERIC. https://files.eric.ed.gov/fulltext/ED545458.pdf

[13] Hattie, J. (2003, October). Teachers Make a Difference What is the research evidence? Building Teacher Quality: What Does the Research Tell Us?, 1-18. https://research.acer.edu.au/cgi/viewcontent.cgi?article=1003\&context=research_conference_2003

[14] Henard, F., \& Roseveare, D. (2012). Fostering Quality Teaching in Higher Education: Policies and Practices. Organisation for Economic Cooperation and Development. https://www.oecd.org/education/imhe/QT\%20policies\%20and\%20practices.pdf

[15] Hobbs, L. (2012). TEACHING 'OUT-OF-FIELD' AS A BOUNDARY-CROSSING EVENT: FACTORS SHAPING TEACHER IDENTITY. International Journal of Science and Mathematics Education, 11(2), 271-297. https://doi.org/10.1007/s10763-012-9333-4

[16] Hobbs, L. (2015, April 12). Too many teachers teaching outside their area of expertise. The Conversation. https://theconversation.com/toomany-teachers-teaching-outside-their-area-of-expertise-39688

[17] House, A. (2009). Improving primary teachers' subject knowledge across the curriculum [E-book]. Office for Standards in Education. https://dera.ioe.ac.uk/305/1/Improving\%20primary\%20teachers\%20subject\%20knowledge\%20across\%20the\%20curriculum.pdf

[18] Hudson, P. (2012). How Can Schools Support Beginning Teachers? A Call for Timely Induction and Mentoring for Effective Teaching. Australian Journal of Teacher Education, 37(7), 71-84. https://doi.org/10.14221/ajte.2012v37n7.1

[19] Hudson, P. (2012, July). Beginning teachers' achievements and challenges: Implications for induction and mentoring. Paper presented at the Australian Teacher Educators Association (ATEA) conference, Glenelg, South Australia. https://metprogram.com/wpcontent/uploads/2015/10/Beginning-teachers-achievements-and-challenges.pdf

[20] Huizinga, T., Nieveen, N., \& Handelzalts, A. (2019). Identifying Needs for Support to Enhance Teachers' Curriculum Design Expertise. Collaborative Curriculum Design for Sustainable Innovation and Teacher Learning, 115-137. https://doi.org/10.1007/978-3-030-20062-6_7

[21] Ingersoll, R. (1998). The Problem of Out-of-Field Teaching. Phi Delta Kappan, 773-776. https://repository.upenn.edu/cgi/viewcontent.cgi?article=1137\&context=gse_pubs

[22] Ingersoll, R. (2001). The Realities of Out-of-Field Teaching. Educational Leadership, 58(8), 42-45. https://repository.upenn.edu/gse_pubs/549/

[23] Ingersoll, R. M. (2000). Out-of-Field Teaching. ERIC Digest. ERIC Clearinghouse on Teaching and Teacher Education Washington DC. https://eric.ed.gov/?id=ED449119

[24] Ingersoll, R., \& J Collins, G. (2018). Schools and Society: A Sociological Approach to Education (6th ed.). Pine Forge Press/Sage Publications. https://repository.upenn.edu/cgi/viewcontent.cgi?article=1226\&context=gse_pubs

[25] Jadama, L. M. (2014). Impact of Subject Matter Knowledge of a Teacher in Teaching and Learning Process. Middle Eastern \& African Journal of Educational Research, 7, 20-29. https://arastirmax.com/tr/system/files/dergiler/79204/makaleler/7/1/arastirmax-impact-subject-matterknowledge-teacher-teaching-and-learning-process.pdf

[26] Kathirveloo, P., Puteh, M., \& Matematik, F. S. (2014). Effective Teaching: Pedagogical Content Knowledge. Proceeding of International Joint Seminar Garut, Garut, Indonesia, 1-8. https://www.researchgate.net/publication/303940850_Effective_Teaching_Pedagogical_Content_Knowledge

[27] Levy, H. M. (2008). Meeting the Needs of All Students through Differentiated Instruction: Helping Every Child Reach and Exceed Standards. The Clearing House: A Journal of Educational Strategies, Issues and Ideas, 81(4), 161-164. https://doi.org/10.3200/tchs.81.4.161-164 
[28] Mack, N., Woodsong, C., Macqueen, K., Guest, G., \& Namey, E. (2005). Qualitative Research Methods: A DATA COLLECTOR'S FIELD GUIDE. Family Health International. https://www.researchgate.net/publication/215666086_Qualitative_Research_Methods_A_Data_Collector's_Field_Guide

[29] Manen, M. V., \& Adams, C. A. (2010). International Encyclopedia of Education (3rd ed.). Elsevier. https://doi.org/10.1016/B978-0-08-0448947.01539-6

[30] Mizell, H. (2010). Why Professional Development Matters (No. ED521618). ERIC. https://eric.ed.gov/?id=ED521618

[31] Mizzi, D. (2013). The Challenges Faced by Science Teachers When Teaching Outside Their Specific Science Specialism. Acta Didactica Napocensia, 6(4), 1-6. https://eric.ed.gov/?id=EJ1053677

[32] Mohd. Salleh, U. K., \& Darmawan, I. G. N. (2013). Differences between In-Field and Out-of-Field History Teachers Influence on Students Learning Experience in Malaysian Secondary Schools. Creative Education, 04(09), 5-9. https://doi.org/10.4236/ce.2013.49b002

[33] Montebon, D. R. T. (2015). Science Pre-Service Teachers Experience on Teaching Beyond Subject Expertise. Journal of Science and Mathematics Education in Southeast Asia, 38(2), 126-139. https://www.researchgate.net/publication/323369642_Science_PreService_Teachers_Experience_on_Teaching_beyond_Subject_Expertise

[34] Omona, J. (2013). Sampling in Qualitative Research: Improving the Quality of Research Outcomes in Higher Education. Makerere Journal of Higher Education, 4(2), 169-185. https://doi.org/10.4314/majohe.v4i2.4

[35] Padilla-Díaz, M. (2015). Phenomenology in Educational Qualitative Research: Philosophy as Science or Philosophical Science? International Journal of Educational Excellence, 1(2), 101-110. https://doi.org/10.18562/ijee.2015.0009

[36] PISA 2018 Results (Volume I). (2019). PISA, 1-2. https://doi.org/10.1787/5f07c754-en

[37] PISA 2018 Results (Volume II). (2019). PISA, 1-376. https://doi.org/10.1787/b5fd1b8f-en

[38] PISA 2018 Results (Volume III). (2019). PISA, 1-368. https://doi.org/10.1787/acd78851-en

[39] Rahman, M. F., Babu, R., \& Ashrafuzzaman, M. (2011). Assessment and Feedback Practices in the English Language Classroom. Journal of NELTA, 16(1-2), 97-106. https://doi.org/10.3126/nelta.v16i1-2.6133

[40] Stronge, J. H., \& Hindman, J. L. (2006). Teacher Quality Index. Association for Supervision and Curriculum Development. http://www.ascd.org/publications/books/105001/chapters/Teacher-Quality-and-Teacher-Selection.aspx

[41] Supovitz, J. A., \& Turner, H. M. (2000). The effects of professional development on science teaching practices and classroom culture. Journal of Research in Science Teaching, 37(9), 963-980. https://onlinelibrary.wiley.com/doi/epdf/10.1002/10982736\%28200011\%2937\%3A9\%3C963\%3A\%3AAID-TEA6\%3E3.0.CO\%3B2-0

[42] Thomas, D. (2014, June 9). Power in the Classroom. Linkedin. https://www.linkedin.com/pulse/20140609082714-324997647-power-in-theclassroom

[43] Valenzuela, A. J. (2019). Recruitment and Selection Process of Faculty in Higher Education Institutions in the Philippines. ELSEVIER, 1-12. https://papers.ssrn.com/sol3/papers.cfm?abstract_id=3445566

[44] Villena, M. G., \& de Mesa, M. C. (2015). Teaching Styles of the Classroom Managers in one Basic Primary School in the Philippines. Asia Pacific Journal of Multidisciplinary Research, 3(2), 113-119. http://www.apjmr.com/wp-content/uploads/2015/06/APJMR-2015-3-2-016-TeachingStyles-of-the-Classroom-Managers-in-Pinamucan-Elementary-School.pdf

[45] Weimer, M. (2009, December 22). Different Sources of Power that Affect the Teacher-Student Relationship. Faculty Focus: Higher Ed Teaching Strategies From Magna Publications. https://www.facultyfocus.com/articles/teaching-and-learning/different-sources-of-power-that-affectthe-teacher-student-relationship/

[46] Weldon, P. R. (2016). Out-of-Field Teaching in Australian Secondary Schools. Australian Council for Educational Research (ACER). https://research.acer.edu.au/cgi/viewcontent.cgi?article=1005\&context=policyinsights 